and birds, and to which a large new aviary has been added. Schools in and about Colombo make increasing use of this collection, and 8,127 scholars visited the Museum with their teachers during the year. Approximately 225,000 people entered the Museum in 1931, amongst which there were three times as many 'strangers' as European residents.

\section{Work of the Meteorological Office}

THE Annual Report of the Director of the Motrorological Cffice for the year ended March 31, 1932 (I, ondon: H.M. Stationery Office. 1s. net.). deals with the soventy-seventh year of the Meteorological Office. Although the work has continued on the main lines followed in recent yoars, this year has seen the conclusion of a scherne of re-organisation of the arrangements made at the London headquarters for the proparation of weather forecasts. Under the revised arrangements a single branch only is concerned with forecasts, whereas formerly forecasts for aviation were done by one branch and all other forecasts by another-an uwkward arrangement involving a certain amount of duplication, and one which is not justified by any essential difference between the two types of forecast. This internal re-organisation has had its counterpart in a simplification of the exchange of weather information by wireless telegraphy between different countries. This year has also seen the commencement of a scheme of co-operation with the Automobile Association in the supply of meteorological information, including forecasts, to private persons flying their own aeroplanes. The only othor work of an exceptional character was in connexion with the second Inter. national Polar Year. A number of countries, including Great Britain, are co-operating in obtaining data from high latitudes for the study of meteorology and terrestrial magnetism, and aro organising expeditions for that purpose. The share allotted to the Meteorological Office consists of an expedition to Fort Rae, in Canada.

\section{Warfare on Eddystone Island}

A communication received from Mr. R. A. Lever of Tulagi, British Solomons, referring to a Research Item in NATURE of June 11, p. 872, based on a paper by Mr. A. M. Hocart on warfare in Eddystone Island of the Solomons (J.Roy. Anthrop. Inst., vol. 61, pt. 2) points out that the only weapons to be seen now among the islanders are light spears and bows and arrows for shooting fish and small birds, while head-hunting, murder and adultery, to which Mr. Hocart had referred as the causes of strife, have long been dealt with under the British protectorate, as in all other parts of the globe where we have any share in the government. In fairness to Mr. Hocart, it must be pointod out that the brief paragraph in our columns summarises a paper of 24 pages. Reference to Mr. Hocart's complete paper will show that he was dealing with conditions in the island when he visited it in 1908-9, and further, that in describing as a whole this aspect of native culture, he covered practices which were obsolete, or had fallen into disuse not long before his visit, as well as customs which he himself observed or of which he was informed. At times, both in his own narrative and in that of his informants, he makes use of the historic present, but the context makes it clear whether he intends a reference to what was then current or to what had become obsolete.

\section{The New York Aquarium}

THE most noteworthy event at the Aquarium of the New York Zoological Society, recorded in the Director's Report for 1931, was the establishment and opening of a new department for the oxhibition of the smaller fresh-water tropical fishes. At the opening in December, 120 species of diminutivo frosh-water fishes from many distant tropical localities were shown, and since many of these are suitable for keeping in home aquaria, part of the exhibit was a demonstration tank showing a balanced aquarium of mixed fishes suitable for such a purpose. The thoroughness with which the world is combed for the stocking of the tropical fresh-water tanks is well illustrated by a map showing collecting grounds in 43 localities, ranging from the Americas to Africa, India, Malays, and Australia. Only one European locality, in Spain, has contributed to the tropical collection and only one to the collection of temporate fishes. An interesting activity of the Aquarium is the distribution from the hatchery of quantities of fish eggs and young fishes at different stages of development to high schools for biological studies. In addition to the year's grant of 76,167 dollars, the City of New York voted 245 dollars towards salaries for temporary labour and 1,000 dollars for the hiring of labourers for 200 days at 5 dollars a day, thereby helping to relieve the condition of unemployment. The Zoological Society provided from its own funds an additional 22,761 dollars. In the course of the year the Aquarium was visited by $2,453,806$ persons.

\section{Destruction of Hawks in the United States}

IT is remarkable that the many ornithological associations in the United States were unable for thirteen years to prevent the State-encouraged slaughter of hawks in Maryland. In a short article in the Condor (1932, p. 187), Prof. A. Brazier Howell gives some indication of what the bounty payment of 50 cents for each hawk (the law was intended to apply to tho sharp-shinned and Cooper's hawks only) meant to the hawk population and to the public purse. From a total of 7 individuals killed in 1918, the year of the passing of the anti-hawk legislation, the annual slaughter reached 20,081 in 1923-24, and 22,283 in $1929-30$, when the bounty was repealed. In all, during the thirteen years when the bounty was in force, 62,543 dollars were paid for 125,086 hawks. Unfortunately, the effect spread far beyond the bounds for which the Maryland legislators were responsible, for the inducement of the bounty led individuals to make a protitable business of hawkhunting, particularly during autumn, when thousands of migrating hawks remain for short periods on passage. In the five years 1926-1930, a well-known

$$
\text { No. 3286, Vol. 130] }
$$

